\title{
Physician Assistant
}

National Cancer Institute

\section{Source}

National Cancer Institute. Physician Assistant. NCI Thesaurus. Code C53423.

A person trained and qualified to provide comprehensive diagnostic, preventive, and

therapeutic medical care and services to patients under the guidance of the physician. A

scope of physician assistant professional activity does not include the full range of interpretation of medical findings requiring the full professional backg round of the licensed physician. PAs are licensed by a state authority. 